States of America. His Majesty's Government have selected and sent Dr. Darwin, the director of the National Physical Laboratory, as director of a Central Scientific Office, working under the direction of the British Supply Council in North America. Dr. Darwin's duty will be to collaborate with United States research bodies, to act as a channel for the exchange with the appropriate United States authorities of technical and scientific information, and generally to co-ordinate scientific and technical inquiries to and from the United States authorities, except in those matters which are already dealt with through the Service attachés. In addition, Dr. Conant, the president of Harvard University, recently visited England as President Roosevelt's representative in order to establish a corresponding mission in this country."

\section{Advisory Committee on Engineering in Warfare}

THE Lord President of the Council, with the approval of the Prime Minister, has appointed an Engineering Advisory Committee under the chairmanship of Lord Hankey to advise the Government upon engineering questions connected with the war effort and in particular: "To consider how the resources of the engineering profession can best be utilized in connexion with the war work of Government departments, and to nominate engineers who might suitably be invited to undertake particular tasks. To suggest means of improving or supplementing the methods adopted by Government departments for utilizing engineering science for war purposes. To advise on problems referred to them in connexion with the development of new engineering devices, and to advise on methods of bringing such devices speedily into production, and on means of meeting now war requirements in the engineering field. To examine new ideas or devices in engineering likely to assist the war effort, to test their technical validity, and to bring to the notice of the Government those which appear to merit further consideration by the department concerned."

The Committee will consist of Lord Hankey, Chancellor of the Duchy of Lancaster (chairman); Lord Falmouth (vice-chairman); Sir Henry Tizard, rector of the Imperial College of Science and Technology. The rest have been selected after consultation with the presidents of the Institutions of Civil Mechanical and Electrical Engineers and are as follows: Mr. J. R. Beard, of Merz and McLellan, consulting engineers; Dr. A. P. M. Fleming, director of the Research and Education Departments, Metropolitan-Vickers Electrical Co. Ltd.; Mr. W. T. Halcrow, consulting engineer ; Prof. B. W. Holman, assistant professor and University reader in mining in the Imperial College of Science and Technology, London; Dr. C. C. Paterson, director of the Research Laboratories, General Electric Co. Ltd. ; Mr. H. R. Ricardo, technical director of Ricardo and Co. Ltd., consulting engineers; Dr. A. Robertson, principal of the Merchant Venturers' Technical College, Bristol.

\section{Post-War Problems for Chemical Industries}

THERE has been an increasing tendency of late for presidential addresses to deal with topics that lie outside the scope of the scientific or technical society concerned. We have had physicists dilating upon metaphysics, chemists on agriculture, biologists on politics, and nearly all on education or economics. This practice is not to be summarily condemned, because it indicates that at least some scientific men are abandoning their old attitude of 'splendid isolation' from human affairs, though at times one is reminded of Bernard Shaw's dictum that no one ever learned to do one thing by doing something else. Mr. F. Heron Rogers, in his address to the nineteenth annual meeting of the Institution of Chemical Engineers, held on April 4 in London, proved no exception to this tendency. In his view, war is inevitable, and the 'fittest' who survive in life's struggles are those who are "strong in arms and in honour".

Probably the most serious after-war problem, says Mr. Rogers, will be that of finance, conjoined with the maintenance of our industries and finding work for all. In planning post-war industries, regard must be had for safety of buildings, etc., and this will be best attained by dispersion and by troglodytic working in caves. Great Britain must be made less dependent upon other countries for its necessities, such as mineral oils, timber and food. A calcium carbide industry is essential for producing acetylene and the numerous useful substances derivable from it, while further research on coal-tar products is needed to increase the number of useful aromatic compounds, like solvents, dyes and intermediates. Basic to our industrial life is research on the problem of eliminating sulphur, phosphorus and arsenic from carbonaceous materials, the solution of which would give an enormous impetus to the iron and steel industries and ease all our metallurgical operations. Research is also needed on the utilization of waste materials, which includes problems of extraction, dehydration, disintegration, pressure-filtering, and similar engineering processes. Given a period free of unwise governmental and political interference, and freedom from subsidized competition, great strides in which chemical engineering would play its part could be made towards post-war safety and happiness.

\section{Psychological Terms used in Head Injuries}

The Brain Injuries Committee of the Medical Kesearch Council, in War Mernorandum No. 4 (London: H.M. Stationery Office. Id. net), has compiled a short glossary of psychological terms commonly used in cases of head injuries. The object of the glossary is to secure a greater measure of uniformity in the terminology used in case-notes of patients with head injuries. There is always some difficulty in defining within fixed limits psychological terms, a difficulty that is increased by the fact that many of the terms are also used in popular speech with somewhat vague reference, for example, confusion, hysteria. When a patient suffering from a psychological 
derangement resulting from, or coincident with, head injury is referred by a physician to a special centre, it would be advantageous if the same meaning were attached to the same words. To further this aim sixteen words in common use have been defined. It is possible that another committee might have arrived at a slightly different phraseology, but although general acceptance cannot be expected, yet here is a very useful beginning, and the glossary will probably have a gradually widening sphere of application. Some of the terms defined are: coma, confusion, delirium, traumatic stupor, concussion, malingering, hysteria.

\section{An Early Marine Engineering Institution}

IN Engineering of April 4, Eng.-Captain E. C. Smith gives a short history of the almost forgotten Institution of Marine Engineers, which existed from 1876 until 1879. It came to a close ten years before the present Institute of Marine Engineers was founded, and it does not appear there was any connexion between the twa. The Institution grew out of a Registry of Sea-Going Engineers, afterwards called the Associated Marine Engineers, founded in the City of London. In January 1876, the Marine Engineering News, the forerunner of the present Marine Engineer, was founded, and the editor of this and the secretary of the Institution were one and the same person, Matthew Augustus Soul, a patent agent. Another leading figure in the activities of both journal and society was Nicholas Proctor Burgh, the writer of several books on engines and steam, on the latter of which he held some unusual views. The other promoters of the Institution were consulting engineers in the City of London. The aims of the Institution were admirable. Papers were to be read, a museum and library formed, and a provident fund started; but evidently affairs did not flourish, for both Institution and News came to a close in 1879 , leaving little trace of their doings.

\section{Meteorology in India}

No drastic changes are indicated in the Report on the Administration of the Meteorological Department of India in 1939-40 (Pp. iii $+35+8$ plates. Delhi : Manager of Publications, 1940. 1.2 rupees; 3s. 9d.). A start has been made on the construction of new buildings at New Delhi for the Upper Air Office, which is to be transferred to that city from Agra. Thirty acres of land have been acquired for this purpose, and the buildings were begun in December 1939; they were expected to be ready for occupation towards the end of 1940. The forecasting office at New Delhi, which was closed as a measure of economy in 1932, at a time of financial stringency, was re-opened, and at about the same time a new wireless station attached to the Poona Meteorological Office began to function. These last two developments allowed the Department to complete its "regional synoptic" scheme for the broadcasting of station weather reports. The stations included in these broadcasts, and in similar broadcasts from Karachi, Calcutta and Rangoon, are shown in plate I of the report, and those included in the "Collective Synoptics" in the same plate.

In addition to carrying on the ordinary routine work, so far as war-time restrictions permitted, special investigations were made, among which was one into the seismological features of the Satpura Range earthquake of March 14, 1938. Daily measurements of ozone in the upper atmosphere were begun at the headquarters' office towards the end of 1939 with the aid of a Dobson photo-electric spectrophotometer. Assistance was given to a scientific expedition from the United States under the leadership of Dr. R. A. Millikan, of the California Institute of Technology, Pasadena, mainly by the staff of Agra Observatory. This expedition made observations of cosmic rays at Agra, Gwalior, Peshawar and Bangalore, using large balloons to which were attached recording electroscopes and ion counters fitted with radio sondes.

\section{New Instruments in Physics}

AN interesting account of the debt of modern physics to recent instruments comes from the Bell Telephone Laboratories in New York and is given by Karl K. Darrow (Review of Scientific Instruments, 12, 1-10; Jan. ; 53-61, Feb. 1941). The instruments are classified into three types according as they are devoted primarily to observation, to measurement or to achieving new conditions. In the first article consideration is given to those instruments in which substances can be subjected to new combinations of physical forces or in which one variable is pushed to extreme limits. Bridgman's scheme for achieving pressures of the order of 100,000 atmospheres, Beams's ultracentrifuge rotating at more than 20,000 turns per second, the piezo-electric or magnetostriction oscillator, the Dickel and Clusius use of convection and thermal diffusion to separate isotopes, the attainment of vacua of the order of $10^{-8}$ or $10^{-9} \mathrm{~mm}$. mercury, by the aid of oil diffusion pumps and 'getters', the attainment of temperatures of only a few hundredths of a degree absolute, and of high electric voltages, and magnetic field strengths are all dealt with. The second article is devoted to instruments of observation and instruments of measurement without enforcing too sharp a distinction to the two types. Both articles are well illustrated and give an excellent idea of the present limits reached in most branches of modern physics. The developments in that protean tool, the thermionic vacuum valve, and its resulting developments in acoustics are so great that another article would have been necessary to deal with them.

\section{The Smithsonian Institution: Annual Report.}

THE report of the Smithsonian Institution for the year ending June 30,1940 , includes the report of the secretary, the financial report of the executive committee of the Board of Regents, together with reports on the United States National Museum, the National Gallery of Art, the National Collection of Fine Arts, the Freer Gallery of Art, the Bureau of American Entomology, the International Exchange Service, the 